ISSN 0258-7122 (Print), 2408-8293 (Online)

Bangladesh J. Agril. Res. 44(4): 609-620, December 2019

\title{
PHYSICAL AND ENGINEERING PROPERTIES OF BARI RELEASED THREE GROUNDNUT VARIETIES
}

\begin{abstract}
M. A. HoQUE ${ }^{1}$
Abstract

The knowledge of the physical characteristics of particles is essential for the designer of agricultural machines. The study was aimed to determine physical and engineering properties of three selected varieties of groundnuts cultivated in Bangladesh such as Dhaka-1, BARI Badam-8 and BARI Badam-9 at safe storage moisture content of $7.5 \%$. One hundred groundnut pods and kernels were randomly selected and the length, width and thickness were measured using a vernier caliper. The geometric mean diameter, sphericity, aspect ratio was calculated using standard formula and measured values. Bulk density, true density, mass and porosity were found through direct weighing and water displacement. Angle of repose of pods and kernels was also measured on wood, glass and mild steel sheet surfaces. BARI Badam-9 had the highest pod geometric mean diameter and BARI Badam- 8 had the highest kernel geometric mean diameter. Sphericity of groundnut pod was the highest for Dhaka-1. Surface area of pod and aspect ratio of both pod and kernel were the highest in BARI Badam-9. Porosity of the pod was the least for BARI Badam-8. Angle of repose of kernel varied on wood and glass. But it was similar for kernel on MS sheet for the varieties. This result will be useful to design and develop groundnut processing equipment for different varietal variability.
\end{abstract}

Keywords: Groundnut, Engineering properties, geometric dimensions, BARI

\section{Introduction}

Groundnut (Arachis hypogaea L.) is one of the important oilseed crops in the world. It is rich in protein and has a high energy value. Groundnut is grown on 26.4 million ha worldwide with a total production of 37.1 million metric tons (Mt) and an average productivity of $1.4 \mathrm{Mt} / \mathrm{ha}$ (GOI, 2008). Groundnut is one of the oilseed crop in Bangladesh on the basis of both in area and production (Biswas et al., 2000). Production area and amount of groundnut in Bangladesh is 36842 ha and 66000 metric tons, respectively (BBS, 2017). All parts of groundnut are consumed such as kernels and oil for human and hay for livestock feeds. It is also processed into cake or further processed into confectionary products or snack food. Groundnut oils used in make-up, medicines, textile materials, cosmetics, nitroglycerin, plastics, dyes and paints as well as many other uses (Firouzi et al., 2009). Groundnut production and marketing play a

${ }^{1}$ Senior Scientific Officer, FMP Engineering Division, Bangladesh Agricultural Research Institute (BARI), Gazipur-1701, Bangladesh. 
significant role in the agricultural economies as the most important sources of employment and income (Ntare et al., 2008).

The knowledge of the engineering and other physical properties of groundnut is very fundamental because they expedite the design and development of equipment for harvesting, handling, separation, oil extraction and other forms of processing agricultural materials (Singh and Goswami, 1996; Chukwu and Sunmonu, 2010). Some studies had been done on properties of groundnut kernels (Olajide and Igbeka, 2003; Aydin, 2007; Davies, 2009, Firouzi et al., 2009, Atasie et al., 2009, Jean-Baptiste, et al., 2012, Fashina et al., 2014). Hossain and Haque (1999) evaluated geometric properties of four Bangladeshi groundnut varieties namely Basanti, Maischar, Jhinga and Tridana. But, there is no study on such properties for BARI developed latest groundnut varieties.

In developing country like Bangladesh, the equipment used in the processing of groundnut has been generally designed without taken into consideration of the physical properties of the seeds. Most of the agricultural processing equipment designed for planting, harvesting, threshing, handling, processing and storage of agricultural materials are largely seen to be of low efficiency in terms of the quality of their output and the economy of using which is largely due to nonavailability of data and other engineering properties such as size, mass, density and sphericity of the materials to design such machines. Akanni et al., (2005) reported that inadequate engineering data of groundnuts have greatly influenced the development of processing machinery. The study of these parameters has become necessary to develop an effective groundnut processing equipment resulting in a low breakage of pods and kernels. Therefore, this study was investigated to obtain some engineering properties of pods and kernels of the three selected groundnut varieties.

\section{Materials and Methods}

The experiment was conducted at Farm Machinery and Postharvest Process Engineering (FMPE) Division, Bangladesh Agricultural Research Institute (BARI), Gazipur, Bangladesh during 2015-16. Three varieties of groundnut commonly cultivated in Bangladesh were identified, selected and collected from Oilseed Research Centre, Bangladesh Agricultural Research Institute (BARI), Gazipur. These were Dhaka-1, BARI Badam-8 and BARI Badam-9 (Table-1). These varieties were selected on the basis that BARI Badam- 8 and BARI Badam9 are trying to replace local and old varieties for better yield and reduce insect and pest susceptibility (BARI, 2017). Samples were collected at maturity from the field and harvesting was done manually. The pods were cleaned to remove all foreign materials (Table-1). 
Table 1. Pictorial views of Pod and Kernel of different groundnut varieties

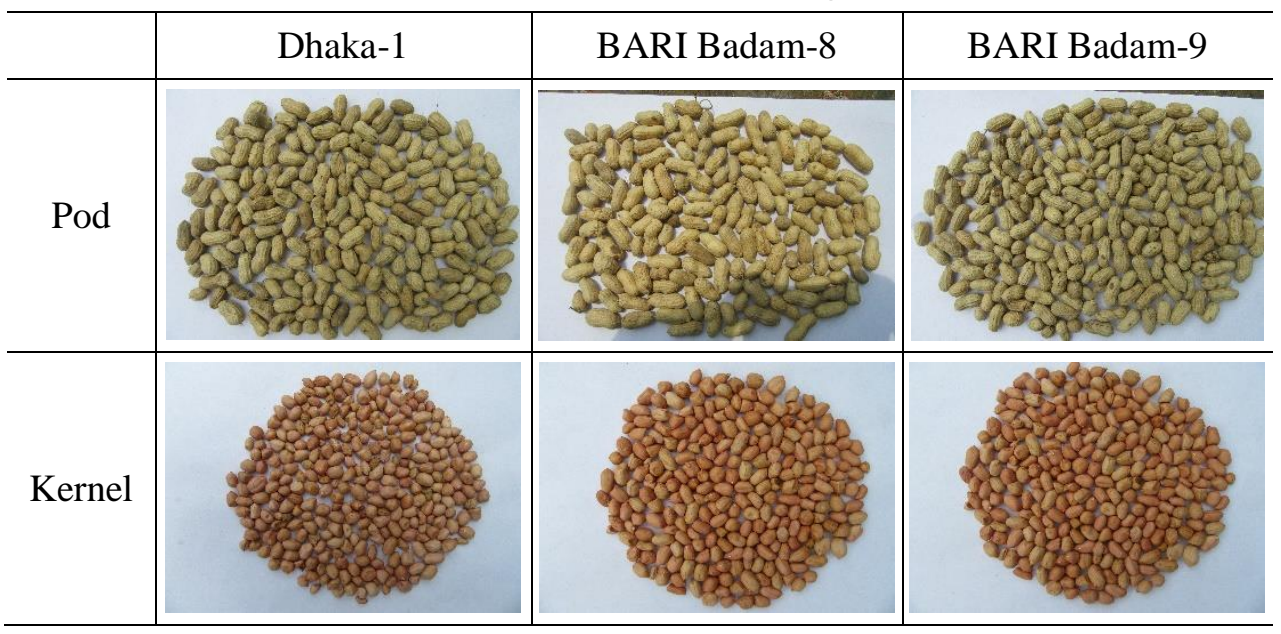

All samples were dried with mechanical dryer and maintained same storage moisture content of $7.5 \%(\mathrm{db})$ for the experiment. The moisture content was determined by drying the samples in an oven at $60^{\circ} \mathrm{C}$ for $12 \mathrm{~h}$ to a constant weight and their respective moisture contents were determined using Equation (1) as suggested by Baumler et al. (2006).

$$
M C(\%)=\frac{W_{w d}-W_{d}}{W_{d}} \times 100
$$

Where,

$$
\begin{aligned}
& M C=\text { Moisture content }(\mathrm{db}), \% \\
& \mathrm{~W}_{\mathrm{wd}}=\text { Initial weight of sample, } \mathrm{g} \\
& \mathrm{W}_{\mathrm{d}}=\text { Final weight of sample, } \mathrm{g}
\end{aligned}
$$

In order to determine dimensions, one hundred groundnut pods were randomly selected. For each pod, the three principal dimensions, namely length, width and thickness of pods and kernels were measured using a vernier caliper having the least count of $0.01 \mathrm{~mm}$. The grain mass was determined using an electronic balance having an accuracy of $0.01 \mathrm{~g}$. The physical properties of the three groundnut varieties were determined by following some equations.

According to Baryeh (2001) and Fashina et al. (2014), the geometric mean diameter, the sphericity and the surface area of groundnut pods and kernels were calculated using the following relationships (Equations (2) to (5)).

$$
\begin{aligned}
& \text { Dgmp }=(L W T)^{1 / 3} \\
& D g m k=(l w t)^{1 / 3}
\end{aligned}
$$




$$
\begin{gathered}
\varphi_{\mathrm{p}}=\frac{\text { Dgmp }}{\mathrm{L}} \\
\varphi_{\mathrm{k}}=\frac{\text { Dgmk }}{1}
\end{gathered}
$$

Where,

$\mathrm{L}=$ pod length, $\mathrm{mm}$

$\mathrm{W}=$ pod width, $\mathrm{mm}$

$\mathrm{T}=$ pod thickness, $\mathrm{mm}$

$\mathrm{l}=$ kernel length, $\mathrm{mm}$

$\mathrm{w}=$ kernel width, $\mathrm{mm}$

$\mathrm{t}=$ kernel thickness, $\mathrm{mm}$

$\mathrm{D}_{\mathrm{gmp}}=$ geometric mean diameter of pod, $\mathrm{mm}$

$\mathrm{D}_{\mathrm{gmk}}=$ geometric mean diameter of kernel, $\mathrm{mm}$

$\varphi_{\mathrm{p}}=$ pod sphericity, $\%$

$\varphi_{\mathrm{k}}=$ kernel sphericity, $\%$

The surface areas $\mathrm{S}\left(\mathrm{cm}^{2}\right)$ of groundnut pods and kernels were calculated using Equations (6) and (7) stated below (Moshenin, 1986 and Jean-Baptiste et al., 2012):

$$
\begin{aligned}
& S_{a p}=\pi \times D_{g m p}{ }^{2} \\
& S_{a k}=\pi \times D_{g m k}{ }^{2}
\end{aligned}
$$

Where:

$$
\begin{aligned}
& S_{a p}=\text { surface area of the pod, } \mathrm{mm}^{2} \\
& S_{\mathrm{ak}}=\text { surface area of the kernel, } \mathrm{mm}^{2}
\end{aligned}
$$

The aspect ratio $(\mathrm{R})$ is the ratio of the width of the pod or the kernel to its respective length which was calculated by applying the following relationships according to Maduako and Faborode (1990):

$$
\begin{aligned}
& \mathrm{R}_{\mathrm{ap}}=\frac{\mathrm{W}}{\mathrm{L}} \times 100 \\
& \mathrm{R}_{\mathrm{ak}}=\frac{\mathrm{W}}{\mathrm{L}} \times 100
\end{aligned}
$$

Where:

$$
\begin{aligned}
& R_{a p}=\text { Aspect ratio of the pod } \\
& R_{a k}=\text { Aspect ratio of the kernel }
\end{aligned}
$$


The bulk density $\left(\rho_{\mathrm{b}}\right)$, which is defined as the ratio of the mass sample of the grains to its total volume, was determined according to Singh and Goswami (1996):

$$
\rho_{b}=\frac{M}{V}
$$

where $\rho_{b}=$ Bulk density, $\mathrm{kg} / \mathrm{m}^{3}$

$M=$ Mass of seeds or kernels, $\mathrm{kg}$

$V=$ Volume occupied, $\mathrm{m}^{3}$

The volumes of randomly selected 100 groundnut pods from each of the three selected varieties were determined by displacement method (Olajide and AdeOmowaye, 1999). Water was poured in a $1000 \mathrm{~cm}^{3}$ capacity measuring cylinder. The initial level was recorded. Three groundnut pods were immersed in the water at a time while noting the new level to which the water rose. Since groundnut pods float in water, a small metal bob was used as a sinker. Its rise in water level was also noted such that it was deducted from the final water level when tied with the groundnut pods. The volume of the groundnut pod was computed by subtracting the volume of the bob from the difference. The experiment was replicated ten times for each variety. The weights of 100 randomly selected groundnut pods and kernels from the three selected varieties were determined by digital electronic weighing balance ( $2 \mathrm{~kg}$ capacity with 0.01 accuracy) as suggested by Milani et al. (2007); Mohsenin (1986). The true density was determined using the unit values of unit volume and unit mass of individual pod and kernel and calculated using the following relationship:

$$
\rho_{t}=\frac{M}{V_{d}}
$$

where $\rho_{t}=$ True density, $\mathrm{kg} / \mathrm{m}^{3}$

$$
\begin{aligned}
& M=\text { Mass of seeds or kernels, } \mathrm{kg} \\
& V_{d}=\text { Volume of water displaced, } \mathrm{m}^{3}
\end{aligned}
$$

The porosity value $(\varepsilon)$ which is defined as the fraction of space in the bulk grain, not occupied by the grain, was calculated from the following relationship (Mohsenin, 1986):

$$
\varepsilon(\%)=\left(1-\frac{\rho_{b}}{\rho_{t}}\right) * 100
$$

Thousand grain weight (g) was determined by weighing 100 seeds and kernels in an electronic balance to an accuracy of $0.01 \mathrm{~g}$ and then multiplying by 10 to get 
the mass of 1,000 grains. The angle of repose $(\theta)$ of pods or kernels was measured by the emptying method in bottomless cylinder (diameter, $5 \mathrm{~cm}$; height, $8.5 \mathrm{~cm}$ ). The cylinder filled with groundnut seeds or kernels was placed on a wooden table, glass sheet and Mild Steel (MS) sheet separately and raised slowly until it forms a heap. The diameter (D) and height $(\mathrm{H})$ of the heap were recorded (Malik and Saini, 2016). Using the following equation, $\theta$ was determined.

$$
\theta=\tan ^{-1} \frac{2 H}{D}
$$

\section{Results and discussion}

Moisture content (MC) of collected samples was maintained at $7.5 \%(\mathrm{db})$ over the experimentation by mechanical drying. Physical properties of groundnut pod and kernel are genetically controlled but the application of these values in practical field is affected by the environmental factors in particular moisture content (Baumler et al., 2006; Yalcin, 2007; Firouzi et al., 2009). Thus, the engineering properties of three selected groundnut varieties of Bangladesh were measured at $7.5 \% \mathrm{MC}$ for both pods and kernels. Frequency distribution of length of pod and kernel of selected three varieties is shown in Fig. 1. Length of pod and kernel of BARI Badam-9 was the highest where pod ranged from 22 to $34 \mathrm{~mm}$ and kernel ranged from 8 to $16 \mathrm{~mm}$ (Fig. 1). Width of kernel ranged from 4 to $10 \mathrm{~mm}$ irrespective of variety and pod width ranged least (10 to 14 $\mathrm{mm}$ ) as shown in Fig. 2. Thickness of kernel also ranged from 4 to $10 \mathrm{~mm}$ irrespective of variety (Fig. 3). Pod width of BARI Badam- 8 and BARI Badam9 ranged from 10 to $14 \mathrm{~mm}$ whereas that of Dhaka-1 ranged within 8 to $16 \mathrm{~mm}$ range (Fig. 2).

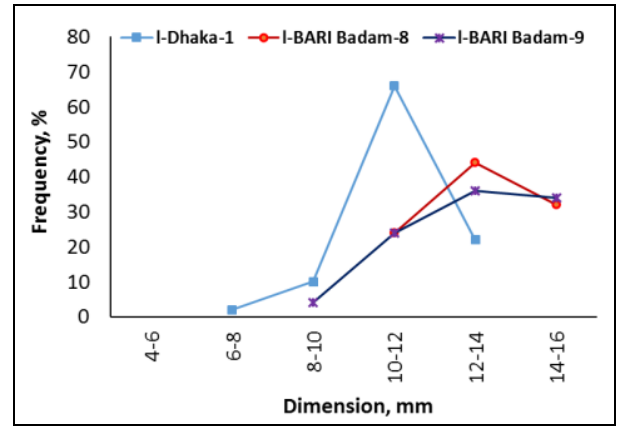

(a) Kernel

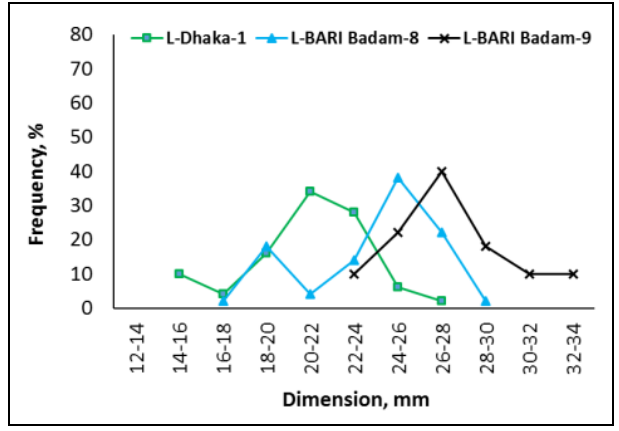

(b) Pod

Fig. 1. Frequency distribution of length of pod and kernel of selected three varieties. 


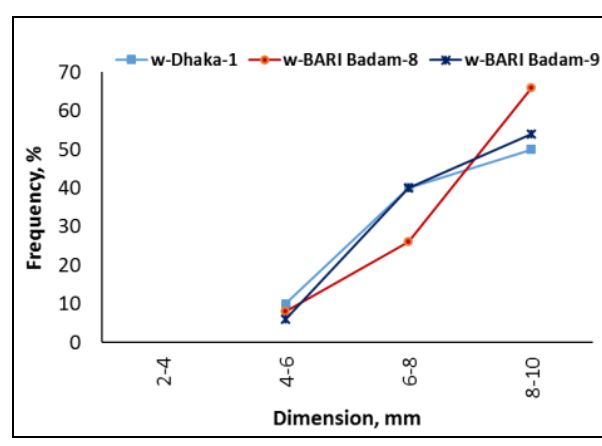

(a) Kernel

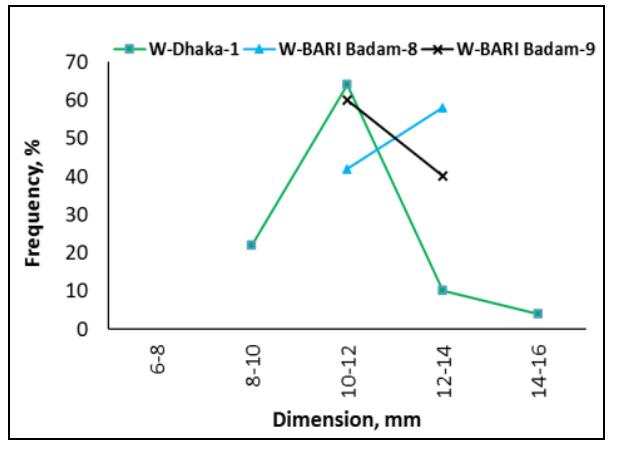

(b) Pod

Fig. 2. Frequency distribution of width of pod and kernel of selected three varieties.

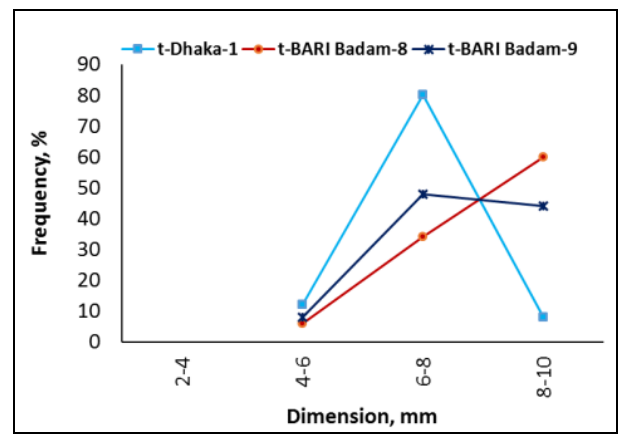

(a) Kernel

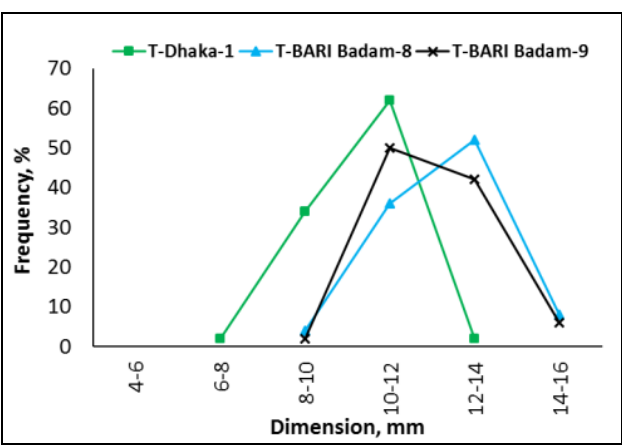

(b) Pod

Fig. 3. Frequency distribution of thickness of pod and kernel of selected three varieties.

Physical dimensions (length, width and thickness) are important parameters which are useful in determining aperture size in grain handling machinery. The average values for the length, width, thickness, geometric mean diameter, sphericity, surface area, aspect ratio, bulk density, true density, porosity, thousand grain weight and angle of repose of the three selected groundnut varieties were measured at moisture content of $7.5 \%(\mathrm{db})$. The determined engineering properties of the groundnut pods are presented in Table 2 while their corresponding values for the kernels were exposed in Table 3. The highest mean length, width and thickness were recorded for BARI Badam-9. It was exposed from the geometric dimensions of these varieties that BARI Badam-9 had the highest pod geometric mean diameter $(12.08 \mathrm{~mm})$ and BARI Badam- 8 had the highest kernel geometric mean diameter $(9.74 \mathrm{~mm})$ (Table 2). The lowest pod and kernel geometric mean diameter were for Dhaka-1. The average dimension of the pods in length, width and thickness of Dhaka-1 were 20.99, 11.20, and $10.46 \mathrm{~mm}$, respectively. Thus, it has been recognized that substantial differences among the three selected groundnut varieties cultivated in Bangladesh were 
found in terms of their geometric dimensions. This is in agreement with the variability for the engineering properties among varieties reported by Fashina et al. (2014); Jean-Baptiste et al. (2012); Firouzi et al. (2009); Olajide and Igbeka (2003)

The ability of the grain to roll or slide depends on its aspect ratio and sphericity. Sphericity of both the groundnut pods and the kernels are dynamic parameter of processing. Sphericity affects how easily grains can be processed by the food industry (Kabas et al., 2001). It also indicates the relative nearness of the product shape to spherical shape. Sphericity of groundnut pod was the highest for Dhaka$1(65 \%)$ though that of kernel was statistically similar for Dhaka-1 and BARI Badam- 8 . The average kernel sphericity was lower than that reported by Olajide and Igbeka (2003) corresponding to the value of $76 \%$ but higher than the values of $51.6 \%$ to $57.1 \%$ obtained by Aydin (2007).

Geometric surface is dependent on length, breadth and thickness which is importantly useful in determination of heat and mass transfer (Adebowale et al., 2011). Surface area of pod was found the highest in BARI Badam-9 $\left(778 \mathrm{~mm}^{2}\right)$ but for kernel, it was the highest in BARI Badam-8 $\left(301 \mathrm{~mm}^{2}\right)$.

The aspect ratio of a product is an indicator which expresses its tendency towards an oblong shape. The study found the aspect ratio of the groundnut pods for Dhaka-1, BARI Badam-8 and BARI Badam-9 varieties to be 54.06, 50.58 and 44.23 , respectively. The corresponding aspect ratio values for the kernels were found to be 71.63, 65.08 and 59.70. Significantly lowest aspect ratio of pod and kernel was found in BARI Badam-9.

Bulk density of BARI Badam-8 was the highest for both pod $\left(342.51 \mathrm{~kg} / \mathrm{m}^{3}\right)$ and kernel $\left(658.56 \mathrm{~kg} / \mathrm{m}^{3}\right)$. The value of kernel agrees with Davies (2009) who found the average density of $753 \mathrm{~kg} / \mathrm{m}^{3}$. Porosity of the pod was the least for BARI Badam-8 (64.06\%) but that of kernel was similar for all varieties.

Seed weight is an important attribute that determines the consumer preference in groundnut cultivars. Kernel weight had positive and significant correlations with geometric surface, degree of sphericity and porosity of the seeds (Jean-Baptiste et al., 2012).

Research findings indicate positive correlation between weight and oil content of groundnut kernels (Dwivedi et al.,1990). Thousand grain weight of BARI Badam- 8 was the highest $(886.67 \mathrm{~g}$ ) among the selected varieties but for kernel, it was statistically similar between BARI Badam-9 (497.33 g) and BARI Badam8 (373.33 g). Relatively lighter pod and kernel were obtained from Dhaka-1 variety. 
Table 2. Some physical and engineering properties of the pods of the selected groundnut varieties at $7.5 \% \mathrm{MC}(\mathrm{db})$

\begin{tabular}{|c|c|c|c|c|c|}
\hline & Dhaka-1 & BARI Badam- 8 & BARI Badam-9 & $\mathrm{CV}$ & HSD \\
\hline Length, mm & $20.99 \pm 2.72^{c}$ & $23.98 \pm 3.20^{\mathrm{b}}$ & $27.09 \pm 2.35^{\mathrm{a}}$ & 10.43 & 1.19 \\
\hline Width, mm & $11.20 \pm 1.24^{\mathrm{b}}$ & $11.88 \pm 1.09^{\mathrm{a}}$ & $11.90 \pm 0.72^{\mathrm{a}}$ & 8.23 & 0.46 \\
\hline Thickness, mm & $10.46 \pm 0.99^{b}$ & $12.44 \pm 1.20^{\mathrm{a}}$ & $12.08 \pm 1.05^{\mathrm{a}}$ & 8.06 & 0.45 \\
\hline $\begin{array}{l}\text { Geometric mean } \\
\text { diameter, } \mathrm{mm}\end{array}$ & $13.46 \pm 1.19^{\mathrm{c}}$ & $15.20 \pm 1.25^{\mathrm{b}}$ & $15.71 \pm 0.87^{\mathrm{a}}$ & 6.24 & 0.44 \\
\hline Sphericity, \% & $64.72 \pm 6.05^{\mathrm{a}}$ & $64.08 \pm 6.17^{\mathrm{b}}$ & $58.24 \pm 3.97^{\mathrm{b}}$ & 8.63 & 0.03 \\
\hline Surface area, $\mathrm{mm}^{2}$ & $574.18 \pm 100.28^{c}$ & $731.17 \pm 116.26^{\mathrm{b}}$ & $777.84 \pm 85.95^{\mathrm{a}}$ & 12.29 & 40.61 \\
\hline Aspect ratio & $54.06 \pm 8.28^{\mathrm{a}}$ & $50.58 \pm 9.37^{\mathrm{a}}$ & $44.23 \pm 4.51^{\mathrm{b}}$ & 14.91 & 3.52 \\
\hline Bulk density, $\mathrm{kg} / \mathrm{m}^{3}$ & $303.87 \pm 5.52^{\mathrm{b}}$ & $342.51 \pm 11.05^{\mathrm{a}}$ & $311.60 \pm 3.03^{\mathrm{b}}$ & 2.01 & 11.58 \\
\hline True density, $\mathrm{kg} / \mathrm{m}^{3}$ & $908.14 \pm 30.35^{\mathrm{b}}$ & $968.43 \pm 12.94^{\mathrm{a}}$ & $970.69 \pm 13.11^{\mathrm{a}}$ & 1.95 & 53.81 \\
\hline Porosity, \% & $66.51 \pm 1.51^{\mathrm{a}}$ & $64.06 \pm 0.77^{\mathrm{b}}$ & $67.93 \pm 0.40^{\mathrm{a}}$ & 1.12 & 2.15 \\
\hline 1000 grain wt, $g$ & $593.33 \pm 23.09^{c}$ & $813.33 \pm 11.55^{\mathrm{b}}$ & $886.67 \pm 30.55^{\mathrm{a}}$ & 2.05 & 45.52 \\
\hline \multicolumn{6}{|c|}{ Angle of repose (degree) on } \\
\hline Wood & $29.28 \pm 0.43$ & $26.24 \pm 0.70$ & $28.66 \pm 2.81$ & 6.60 & $\mathrm{~ns}$ \\
\hline Glass & $28.51 \pm 0.47$ & $24.94 \pm 2.18$ & $26.22 \pm 1.76$ & 7.47 & ns \\
\hline MS Sheet & $28.76 \pm 2.00$ & $25.03 \pm 2.63$ & $26.97 \pm 1.78$ & 5.70 & ns \\
\hline
\end{tabular}

Foot notes: Value is for Mean \pm sd; Similar letter in same rows did not significantly varied

The angle of repose of a granular material is the steepest angle of descent or dip of the slope relative to the horizontal plane when material on the slope face is on the edge of sliding. Angle of repose of groundnut pod on wood, glass and MS sheet did not vary for the selected varieties. Again, angle of repose of kernel was statistically similar for BARI Badam- 8 and BARI Badam-9 but significantly higher than that found for Dhaka-1 on wood and glass. But angle of repose did not vary for kernel on MS sheet for the varieties. This might be due to the relative smoothness of the surface of the kernels. Results found from this experiment were similar to that of Davies (2009) who noted the angle of repose as $28^{\circ}$ for pod at moisture content of $7.6 \%(\mathrm{db})$.

The angle of repose was higher for pod than kernel on all surfaces as evaluated. This is because groundnut pods are more cohesive than kernels. Eventually more cohesive surface of the tested grain will have higher angle of repose which were also reported on sunflower (Santalla and Mascheroni, 2003) and Canavalia (Niveditha et al., 2013). 
Table 3. Some physical and engineering properties of the kernels of the selected groundnut varieties at $7.5 \% \mathrm{MC}(\mathrm{db})$

\begin{tabular}{|c|c|c|c|c|c|}
\hline & Dhaka-1 & BARI Badam-8 & BARI Badam-9 & $\mathrm{CV}$ & HSD \\
\hline Length, mm & $11.24 \pm 1.13^{\mathrm{b}}$ & $13.27 \pm 1.55^{\mathrm{a}}$ & $13.16 \pm 1.63^{\mathrm{a}}$ & 11.64 & 0.70 \\
\hline Width, mm & $8.02 \pm 1.09^{\mathrm{b}}$ & $8.59 \pm 1.02^{\mathrm{a}}$ & $7.84 \pm 1.61^{\mathrm{ab}}$ & 15.39 & 0.60 \\
\hline Thickness, mm & $7.12 \pm 0.83^{\mathrm{b}}$ & $8.18 \pm 0.99^{\mathrm{a}}$ & $7.75 \pm 1.23^{\mathrm{a}}$ & 12.73 & 0.47 \\
\hline $\begin{array}{l}\text { Geometric mean } \\
\text { diameter, } \mathrm{mm}\end{array}$ & $8.61 \pm 0.89^{c}$ & $9.74 \pm 0.93^{\mathrm{a}}$ & $9.24 \pm 1.29^{b}$ & 10.84 & 0.47 \\
\hline Sphericity, \% & $76.83 \pm 5.55^{\mathrm{a}}$ & $73.81 \pm 6.24^{\mathrm{a}}$ & $70.41 \pm 8.27^{b}$ & 9.35 & 0.03 \\
\hline Surface area, $\mathrm{mm}^{2}$ & $235.57 \pm 47.16^{\mathrm{c}}$ & $300.94 \pm 54.80^{\mathrm{a}}$ & $273.14 \pm 67.84^{\mathrm{b}}$ & 20.31 & 26.09 \\
\hline Aspect ratio & $71.63 \pm 8.71^{\mathrm{a}}$ & $65.08 \pm 7.43^{\mathrm{b}}$ & $59.70 \pm 12.16^{\mathrm{c}}$ & 15.17 & 4.73 \\
\hline $\begin{array}{l}\text { Bulk } \\
\text { density, } \mathrm{kg} / \mathrm{m}^{3}\end{array}$ & $630.94 \pm 6.05^{\mathrm{c}}$ & $658.56 \pm 7.20^{\mathrm{a}}$ & $647.51 \pm 4.62^{\mathrm{b}}$ & 0.89 & 10.37 \\
\hline $\begin{array}{l}\text { True } \\
\text { density, } \mathrm{kg} / \mathrm{m}^{3}\end{array}$ & $930.31 \pm 41.55$ & $983.33 \pm 28.87$ & $994.67 \pm 23.44$ & 4.00 & ns \\
\hline Porosity, \% & $31.99 \pm 3.63$ & $32.55 \pm 1.54$ & $34.99 \pm 1.56$ & 8.78 & $\mathrm{~ns}$ \\
\hline 1000 grain wt, $g$ & $241.33 \pm 8.08^{c}$ & $373.33 \pm 11.55^{\mathrm{a}}$ & $497.33 \pm 11.72^{\mathrm{a}}$ & 3.21 & 34.69 \\
\hline \multicolumn{6}{|c|}{ Angle of repose (degree) on } \\
\hline Wood & $17.76 \pm 0.66^{\mathrm{b}}$ & $20.05 \pm 0.80^{\mathrm{a}}$ & $20.67 \pm 0.21^{\mathrm{a}}$ & 3.00 & 1.70 \\
\hline Glass & $16.77 \pm 2.18^{b}$ & $19.55 \pm 1.41^{\mathrm{a}}$ & $19.27 \pm 1.39^{\mathrm{ab}}$ & 4.73 & 2.55 \\
\hline MS Sheet & $17.67 \pm 1.57$ & $19.87 \pm 2.38$ & $19.65 \pm 1.85$ & 10.71 & $\mathrm{~ns}$ \\
\hline
\end{tabular}

Foot notes: Value is for Mean \pm sd; Similar letter in same rows did not significantly varied

\section{Conclusions}

BARI Badam-9 had the highest pod geometric mean diameter and BARI Badam- 8 had the highest kernel geometric mean diameter at moisture content of $7.5 \%$ (d.b). The lowest pod and kernel geometric mean diameters were for Dhaka-1. Sphericity of groundnut pod was the highest for Dhaka-1. Surface area of pod was the highest in BARI Badam-9. Aspect ratio of pod and kernel was the lowest in BARI Badam-9. Porosity of the pod was the least for BARI Badam-8. Angle of repose of kernel was statistically similar for BARI Badam-8 and BARI Badam-9 on wood and glass. But angle of repose did not vary for kernel on MS sheet for the varieties. The results thus help the designers to design an efficient groundnut processing machines for groundnut varieties in Bangladesh. 


\section{Acknowledgement}

The author acknowledge the authority of Bangladesh Agricultural Research Institute, Gazipur to allow fund and facilities for this research.

\section{References}

Adebowale, A.A., S.A. Sanni, and O.A. Falore. 2011. Varietal differences in the physical properties and proximate composition of elite sesame seeds. World J. of Agric. Sci. 7(1): 42-46.

Akanni, M.S., A.S. Adekunle and E.A. Oluyemi. 2005. Physico-chemical properties of some non-conventional oil seeds. J. of Food Tech. 3: 177-181.

Atasie, V.N., T.F. Akinhanmi and C.C. Ojiodu. 2009. Proximate Analysis and PhysicoChemical Properties of Groundnut (Arachis hypogaea L.). Pakistan J. of Nutri. 8: 194-197.

Aydin, C. 2007. Some engineering properties of peanut and kernel. J. of Food Eng. 79. 810-816.

Baryeh, E.A. 2001. Physical properties of Bambara groundnuts. J. of Food Eng. 47(4): 321-326.

Baumler, E., H. Cuniberti, S.M. Nolasso and I.C. Riccobene. 2006. Moisture dependent physical and compression properties of safflower seed. J. of Food Eng. 72(2): 134-140.

Biswas, G.C., S. Begum and M.Y. Mian. 2000. Leaf infestation and yield loss caused by thrips and jassids in groundnut. J. of Asiatic Society Bangladesh Sci. 26(2): 253-258.

BBS. 2017. Bangladesh Bureau of Statistics. Statistical Pocket Book. Ministry of planning, Government of the People's Republic of Bangladesh, Dhaka.

BARI. 2017. Bangladesh Agricultural Research Institute Krishi Projukti Hat Boi, Gazipur.

Chukwu, O. and M.O. Sunmonu. 2010. Determination of Selected Engineering Properties of Cowpea (Vigna unguiculata) Related to Design of Processing Machines. Int. J. of Eng. and Tech. 2(6): 373-378.

Davies, R.M. 2009. Some Physical Properties of Groundnut Grains Research. J. of Applied Sci. Eng. and Tech. 1(2): $10-13$.

Dwivedi, S.L., R. Jambunathan, and S.N. Nigam. 1990. Relationship of seed mass to oil andprotein contents in peanut (Arachis hypogaea L.). Peanut Sci. 17(2): 48-52.

Fashina, A.B., A. Saleh and F.B. Akande. 2014. Some engineering properties of three selected groundnut (Arachishypogaea L.) varieties cultivated in Nigeria. Agric Eng Int: CIGR J. 16(4), 268-277. Open access at http://www.cigrjournal.org

Firouzi, S., M.N.S. Vishgaei and B. Kaviani. 2009. Some physical properties of groundnut (Arachishypogaea L.) Kernel cv. NC2 as a function of moisture content. American-Eurasian J. of Agri. and Env. Sci. 6(6): 675-679

GOI. 2008. Economic Survey of India (2008), Government of India, New Delhi.

Hossain M.A. and M.A. Haque. 1999. Geometric properties of groundnut kernels. Tropical Agri. Res. and Ext. 2(2): 107-110. 
Jean-Baptiste, N.T., G. Souina, N.Y. Nicolas, N.M. Richard and Z.Z. Arlette. 2012. Genetic variability and heritability estimates of some properties of groundnut (ArachishypogaeaL.) kernels. Int. J. of Biosci. 2(1): 25-35.

Kabas, O., E. Yilmaz, A. Ozmerzi and I. Akinci. 2007. Some physical and nutritional properties of cowpea seed (Vigna sinensis L.). J. of Food Eng. 79: 1406-1409.

Maduako, J.N. and M.O. Faborode. 1990. Some physical properties of cocoa pods in relation to primary processing. J. of Tech. 2: 1-7.

Malik, M.A. and C.S. Saini. 2016. Engineering properties of sunflower seed: Effect of dehulling and moisture content. Cogent Food and Agri. 2: 1145783 http://dx.doi.org/10.1080/23311932.2016.1145783

Milani, E., M. Seyed, A. Razavi, A. Koocheki, V. Nikzadeh, N. Vahedi, M. Moein Fard, and G. H. A. Pour. 2007. Moisture dependent physical properties of cucurbit seeds. Int. Agrophysics 21(2): 157- 168.

Mohsenin, N. N. 1986. Physical Properties of Plant and Animal Materials. Seconded. Gordon and Breach, Science Publishers Inc., One Park Avenue, New York 10016. 58 -76 .

Niveditha, V. R., K. R. Sridhar, and D. Balasubramanian. 2013. Physical and mechanical properties of seeds and kernels of Canavalia of coastal sand dunes. Int. Food Res. J. 20: $1547-1554$.

Ntare, B.R, A.T. Diallo, J. Ndjeunga and F. Waliyar. 2008. Groundnut Seed Production Manual. Patancheru 502 324, Andhra Pradesh, India: Int. Crops Res. Inst. for the Semi-Arid Tropics (ICRISAT). 20 pp.

Olajide, J.O. and B.I.O. Ade-Omowaye. 1999. Some Physical Properties of Locust Bean Seed. J. of Agri. Eng. Res. 74(2): 213-215.

https://doi.org/10.1006/jaer.1997.0243

Olajide, J.O. and J.C. Igbeka. 2003. Some physical properties of groundnut kernels. J. of Food Eng. 58(2): 201-204.

Santalla, E. M. and R. H. Mascheroni 2003. Note: Physical properties of high oleic sunflower seeds. Food Sci. and Tech. Int. 9: 435-442.

http://dx.doi.org/10.1177/1082013203040756

Singh, K. K. and T. K. Goswami. 1996. Physical properties of cumin seed. J. of Agri. and Eng. Res. 64(2): 93-98.

Yalcin, I., C. Ozarslan, and T. Akbas. 2007. Physical properties of pea (Pisum sativum) seed. Jo. of Food Eng. 79(2): 375-384. 